NBER WORKING PAPER SERIES

\title{
PRISON-BASED EDUCATION AND RE-ENTRY INTO THE MAINSTREAM LABOR MARKET
}

\author{
John H. Tyler \\ Jeffrey R. Kling \\ Working Paper 12114 \\ http://www.nber.org/papers/w12114 \\ NATIONAL BUREAU OF ECONOMIC RESEARCH \\ 1050 Massachusetts Avenue \\ Cambridge, MA 02138 \\ March 2006
}

Tyler: Brown University, National Center for the Study of Adult Learning and Literacy, and National Bureau of Economic Research; Kling: Princeton University and National Bureau of Economic Research. The authors wish to thank William Bales, John L. Lewis, Brian Hays, and Stephanie Bontrager of the Florida Department of Corrections and Duane Whitfield of the Florida Education and Training Placement Information Program for providing the data; and Aaron Sparrow and Thu Vu for invaluable research assistance. We also thank seminar participants at Michigan, Illinois, MIT, UCLA, RAND, UC-Berkeley, Maryland, UC-Davis, and Case Western for helpful comments. This research was partially supported with grants from the Russell Sage Foundation. Additional support was provided by the National Science Foundation (SBE-9876337), the Princeton Office of Population Research (NICHD 5P30-HD32030), the National Center for the Study of Adult Learning and Literacy, and the Princeton Industrial Relations Section. The views expressed herein are those of the author(s) and do not necessarily reflect the views of the National Bureau of Economic Research.

(O2006 by John H. Tyler and Jeffrey R. Kling All rights reserved. Short sections of text, not to exceed two paragraphs, may be quoted without explicit permission provided that full credit, including $\odot$ notice, is given to the source. 
Prison-Based Education and Re-Entry into the Mainstream Labor Market

John H. Tyler and Jeffrey R. Kling

NBER Working Paper No. 12114

March 2006

JEL No. J31, J38

\begin{abstract}
$\underline{\text { ABSTRACT }}$
We estimate the post-release economic effects of participation in prison-based General Educational Development (GED) programs using a panel of earnings records and a rich set of individual information from administrative data in the state of Florida. Fixed effects estimates of the impact of participating in the GED education program show post-release quarterly earnings gains of about 15 percent for program participants relative to observationally similar non-participants. We also show, however, that these earnings gains accrue only to racial/ethnic minority offenders and any GED-related earnings gains for this group seem to fade in the third year after release from prison. Estimates comparing offenders who obtained a GED to those who participated in GED-related prison education programs but left prison without a GED show no systematic evidence of an independent impact of the credential itself on post-release quarterly earnings.
\end{abstract}

John H. Tyler

Education Department

Brown University

Box 1938

Providence, RI 02912

and NBER

john tyler@brown.edu

Jeffrey R. Kling

The Brookings Institution

1775 Massachusetts Avenue, NW

Washington, DC 20036-2188

and NBER

jkling@brookings.edu 


\section{Introduction}

A troubling fact associated with the historically high incarceration rates of the last twenty years is that they have had a disproportionate effect on disadvantaged and minority men, individuals who have traditionally maintained marginal positions in the mainstream labor market. An important question therefore is to what extent education and training programs generally available in correctional facilities help criminal offenders successfully reintegrate into the mainstream labor market. One of the most ubiquitous education opportunities available to inmates who lack a high school diploma is the ability to study for and obtain a General Educational Development (GED) credential. ${ }^{1}$

Prior research on the effects of "prison GEDs" on post-release outcomes is relatively limited in spite of the fact that the 2000 Census of State and Federal Correctional Facilities (Bureau of Justice Statistics 2003) showed that 83 percent of the state correctional facilities in the U.S. offered "secondary education programs," of which the primary type are GED preparation programs. Furthermore, virtually all of the previous research has examined the relationship between obtaining a GED and the probability of recidivating, giving little attention to whether or not prison GEDs are related to post-release labor market outcomes. The widespread availability of the GED credentialing program for incarcerated individuals raises the question of whether there are, in fact, any post-release economic benefits associated with participation in a prisonbased GED program. ${ }^{2}$

\footnotetext{
${ }^{1}$ To obtain a GED individuals have to pass exams that cover math, science, social studies, reading, and writing. All of the test items are multiple choice except for a section in the writing exam that requires GED candidates to write an essay. The total test time if all tests are taken at the same time is about seven and three-quarters hours.

${ }^{2}$ While there has been little research examining the potential effects of passing the exams and obtaining a GED in prison or jail, there has been substantial work in the past ten years on the general labor market effects of a GED. Cameron and Heckman (1993) showed that GED holders were not the labor market equivalents of regular high school graduates. Recent work has tended to indicate that dropouts who leave school with very low skills benefit
} 
Past research on prison-based education programs has been plagued with the fierce selection issues that determine participation in these programs and data that has been largely unsuited to addressing these issues. Furthermore, the prior work in this area has considered only a single counterfactual: what is the impact of participating in prison-based education versus not participating. We advance this line of inquiry in two ways. First, we are able to utilize a much richer and more appropriate data set than has previously been available for examining the impact of prison-based education programs. Second, we examine prison-based GED programs relative to two separate and policy-relevant counterfactuals.

The first research question we examine is the post-release economic value to inmates of having a prison-based GED program. The research here compares the outcomes of inmates who obtained a prison-based GED to those of dropout offenders who did not participate in any prisonrelated GED education. This exercise addresses the question of what would we expect if there were no prison-based secondary education program. On this question we find that minority offenders who obtained a "prison GED" had earnings gains of about 15 percent in the first two years post-release relative to observationally similar minority offenders who did not participate in GED-related education programs while in prison. We find no post-release benefits for white offenders, and we also find that any earnings gains for minority offenders dissipate after two years.

Our second research question is whether or not there is any value in obtaining a "prison GED” relative to participating in prison-based GED education, but leaving prison without the

from obtaining a GED, while there are no payoffs to the credential for dropouts who leave school with higher skills (Murnane, Willett, and Boudett 1999; Murnane, Willett, and Tyler 2000; Tyler, Murnane, and Willett 2000).

Estimates from these studies generally show that after about five years, the earnings of low skilled dropouts who obtain a GED are 15-20 percent higher than those of low skilled uncredentialed dropouts. Heckman, Hsse, and Rubinstein (2000) (HHR) do not find the same pattern as the aforementioned studies. An important difference in the two sets of findings is that HHR do not allow time for the effects of the GED to accrue, a result that the other authors found to be important. 
credential. This parameter approximates the post-release signaling value of the GED in the labor market. We find, at most, only weak evidence of a signaling effect of the GED credential and only for minority offenders.

To conduct this research, we worked with the Department of Corrections in Florida to create a unique administrative data set containing information on individuals who were in a Florida state prison at any time between 1994 and 1999, linked to demographics, education program participation, and earnings records. Our earnings measures are based on working in the mainstream economy (specifically, jobs covered by unemployment insurance). We do not attempt to study total income, but rather focus on the more proximate objective of most public policy directed toward former inmates-legitimate taxpaying employment-for which we can construct a panel of data for individuals for years both before and after prison spells. Using these data we estimate separate models for white and minority group offenders because we believe there are important differences in the background characteristics of these groups that could affect their post-release labor market potential. ${ }^{3}$

We have no clear exogenous source of variation in GED status in our sample, and as a result we suggest caution in attaching a strictly causal explanation to our findings. While we control for all time-invariant heterogeneity, it could be the case that unmeasured, time-varying differences between offenders who do and do not obtain a prison-based GED lend an unknown bias to our

\footnotetext{
${ }^{3}$ In particular, minority group offenders tend to be younger and are more likely to be in prison for a drug-related offense than are the white offenders in our data. The median age of minority group offenders upon prison entry is 24 years-old, while the white offenders in our data are 28 when we observe them entering the prison spell of interest. In terms of offense type, 13 percent of the minority offenders in our data are in prison on a drug-related charge, while only five percent of the white offenders are in prison for crimes related to drug use or distribution. Meanwhile, 19 percent of the white offenders are in prison for crimes related to property theft and/or burglary, while only 10 percent of the minority offenders are incarcerated for property-related crimes. Overall, the distribution of minority offenders in Florida's prisons in the middle to late 1990s is different from that for white offenders in ways that may be related to labor market potential, the prison-GED experience, or to both. For our purposes, "minority group members" refers to everyone who is not coded as white, non-Hispanic in the data. For expositional simplicity minority group members will often be referred to as "minority offenders" in this paper.
} 
results. For example, if offenders for whom the prison experience is a positive life-altering transformation also tend to obtain a GED, our findings overestimate the causal impact of a GED on post-release earnings. If on the other hand, inmates who become more criminally socialized while in prison tend to enroll in GED programs to curry favor with prison officials, our findings would underestimate the causal impact of prison GEDs. Nevertheless, we believe that our estimates give the best look to date at the effectiveness of this major prison-based education program. Furthermore, since we show that our preferred estimates are substantially smaller than naïve estimates mirroring prior research, we believe it likely that earlier work in this area has overestimated the benefits of prison-based education programs.

The remainder of the paper is organized as follows. Section II describes our conceptual framework. Section III discusses our data. Our analytical methods are presented in section IV. Section V presents descriptive statistics, and regression results are reported in section VI. Section VII concludes.

\section{Conceptual Framework}

There are at least two mechanisms through which the GED could increase wages or employment for incarcerated individuals. ${ }^{4}$ First, to the extent that individuals have to study and learn new skills to pass the GED exams, they may increase their human capital, which in turn may lead to increased wages (Becker 1993). This may be an especially important avenue for incarcerated GED candidates, since their pre-GED skill levels are likely lower than those of dropouts in the "free world." Second, the GED may serve as a "labor market signal" allowing

\footnotetext{
${ }^{4}$ In principle, the GED could positively impact labor market outcomes if inmates use their GED to obtain postincarceration higher education or training, but this is not likely to be an important mechanism since the data indicate that GED holders obtain very little post-secondary education or company-provided training (Boudett 2000; Murnane, Willett, and Tyler 2000; Tyler 2001).
} 
employers to identify individuals they suspect of having productive attributes such as higher cognitive skills or motivation levels within the pool of dropout job applicants (Spence 1973).

A key issue in studying the effect of the GED on labor market outcomes is the omitted variable problem: individuals who obtain GEDs in prison may have had attributes that would have led to superior labor market outcomes than non-GED holders even if they did not have a GED. For example, a GED may simply be a proxy for intelligence or motivation that would have lead to greater employment and earnings anyway, with no causal role for the GED itself.

Attention to omitted variables in studying the effects of correctional education on subsequent outcomes has been limited. A 1999 survey of the literature by Wilson et al. (1999) cited eight studies that included an evaluation of the relationship between the GED or the GED plus some additional Adult Basic Education (ABE) and the likelihood of returning to prison -the principal outcome in nearly all studies of the impacts of correctional education. Five of the eight studies found that offenders who obtained a GED were less likely to recidivate than those who did not. However, the authors of the research review point out that "... all of these studies had weak research methodologies, simply comparing either participants with nonparticipants or program noncompleters, with little to no control or adjustment for selection bias" (Wilson et al. 1999, pg. 14). A review that directly discussed the models used to study the impact of correctional education programs on outcomes states that " $[\mathrm{t}]$ he control variables were generally restricted to gender, race, and age... [and only one study] controlled for important sources of selection bias between participants and nonparticipants, such as prior criminal history, in the analysis of recidivism” (Wilson, Gallagher, and MacKenzie 2000, pg. 355).

We are aware of only one study that focused specifically on the linkage between prisonbased education programs and labor market outcomes. The work of Steurer, Smith, and Tracy 
(2001) found higher subsequent earnings among education program participants. ${ }^{5}$ Unfortunately, this study does not separate participation in GED preparation programs from participation in other prison-based education programs such as Adult Basic Education classes and English Second Language classes, so it is not clear what we learn from it about the GED.

Wilson et al. (2000) point to several potential selection mechanisms that could lend an upward bias to the estimated impact of correctional education programs on post-release outcomes. Selection mechanisms in the prison setting could work through both individual choices and through administrative procedures, since enrollment in correctional education programs is predicated on variables such as good behavior and time to release. Fixed characteristics of the individual such as self-control or motivation that might affect post-release outcomes could also affect placement in a GED program through both self- and administrative selection processes. More transitory characteristics such as motivation toward positive life changes and attitudes towards society and towards work could work in the same ways. ${ }^{6}$

There could also be unobserved fixed and transient factors that could lead to underestimates of the causal impact of GED program participation. For example, in interviews of offenders just

\footnotetext{
${ }^{5}$ This study uses prison records linked to UI earnings, as we do. Relative to offenders with no participation in prison-based education programs, unconditional estimates indicated that the "treatment" group of offenders who received some prison-based educational services had lower estimated recidivism rates three years after release, though the differences were not statistically significant. The treatment group also had higher annual earnings in the first, second, and third years after release. Only the first year earnings differences were statistically significant $(\$ 7,775$ versus $\$ 5,980)$, and the estimated differences declined over time. There were no discernable differences in employment rates between those who did and did not receive education programming while in prison.

${ }^{6}$ Sampson and Laub (1993) and Thornberry and Christenson (1984) indicate that program participants may have a higher level of social bond to conventional, non-criminal society than do program nonparticipants. These authors posit that program participants may be more likely to be married, to have children with whom they are in contact, to have had a job before incarceration, and so. Assuming such factors lead to more positive post-release outcomes, failure to control for such attributes will lead to overestimates of the effect of education program participation on outcomes. Zamble and Porporino (1988) offer a conjecture that a sentence to prison may act as a critical life event for some offenders resulting in a change in motivation to both participate in correctional programs and conduct one's life in a more positive manner post-release. In this model any estimated program effects could simply be measures of the commitment of program participants to a life away from crime rather than effects of the program itself on outcomes.
} 
prior to release Steurer, Smith, and Tracy (2001) found that prison-education program participants had lower levels of motivation in regard to several labor market activities including the "motivation to get a job, a better job, or higher pay" or the "motivation to improve job performance" than did program non-participants. At the same time, offenders in the Steurer et al study who participated in prison-based education programs indicated a higher motivation to both "look good to prison or parole officials to get out" and to "get a better situation in prison" than did offenders who did not participate in education programming while in prison. ${ }^{7}$ Thus, in their study participation in education programming seemed to be driven more by a desire to impress prison and parole officials and improve one's situation in prison than by a desire to impact one's post-release labor market outcomes.

One consistent lesson from the prior research on correctional-based education programs is that the positive effects found in the literature are perhaps compromised by research designs that fail to account, even in the most rudimentary ways, for unobserved heterogeneity between program participants and nonparticipants. We attempt to address these shortcomings both through our use of rich data and through fixed effects estimation that has not been previously employed.

\footnotetext{
${ }^{7}$ Neither of these differences between the treatment and comparison group was statistically significant at the 0.01 level, but the mean differences on the five-point Likert scale variables were non-trivial. On the question "motivation to look good to prison or parole officials to get out," the mean for education program participants was 2.77 and that for the comparison group was 2.65. On the question "motivation to get a better situation in prison" the respective results were 2.55 and 2.45 (Steurer, Smith, and Tracey 2001). The only question in the "motivation survey" of Steurer that showed a statistically significant response at the 0.01 level was a question about the "motivation to feel better about self" where the comparison group scored 0.11 mean points higher, suggesting that the responses cited above were likely close to statistical significance, something that cannot be determined from the reported results in the paper.
} 


\section{Data}

To determine whether ex-convicts who acquire a GED while in prison fare better in the mainstream labor market than former offenders who do not possess the credential, we use a unique data set constructed for this project by the Florida Department of Corrections (DOC), the Florida Department of Law Enforcement, and the Florida Education and Training Placement Information Program. About 10,000 of the approximately 144,000 dropouts who were entered a Florida prison at some time between 1992 and 2000 obtained a GED while they were incarcerated. ${ }^{8}$ The master data set from Florida contains basic demographic, criminal justice, and test score information, along with the quarterly earnings for males who were incarcerated in Florida state prisons any time between 1994 and 2000. Quarterly earnings for the sample come from the Florida Unemployment Insurance (UI) system and cover the third quarter of 1993 through the first quarter of 2002. All earnings are deflated to 2002 constant dollars using the CPI-U deflator.

We include in our analysis individuals who had a new commitment to a Florida prison after October 1994 and who had expected release dates that were early enough to allow for at least 12 quarters of post-release data. ${ }^{9}$ The master data set from which we form our analytic sample contains information on 24,764 males who fit this criterion. Among these individuals are 2,957

\footnotetext{
${ }^{8}$ In Florida, offenders housed in virtually all state prisons have the opportunity to test for the GED provided they meet certain guidelines. We note that the count of 144,000 dropouts includes individuals for whom information on education level is missing. When the statistics are limited to individuals for whom education level is known, there are about 108,000 dropouts who entered Florida prisons between 1992 and 2000.

${ }^{9}$ As a result of the 12-quarter criterion, no one in our analytic data set entered prison after March, 1999. Individuals admitted to a Florida prison prior to December 1994 were eligible for "control release." Control release is an administrative function that was used to manage the state prison population within lawful capacity. In the era of control release many inmates were not in prison long enough to participate in academic programs, and those who were likely differed in important ways from prisoners who were being granted control release. As a result, we have limited our analysis to individuals who were admitted to Florida prisons after control release was terminated. We actually use people who were admitted on or after October 1, 1994, because in our data no offenders admitted during October and November of 1994 were given a control release.
} 
offenders who obtained a GED while incarcerated in a Florida prison at some time between October 1994 and March 1999. We are able to use data on 1,967 GED holders who have valid Social Security numbers (discussed below) and non-missing values on key variables used in the analysis. We also analyze 10,989 offenders who both lacked a high school diploma when they entered prison and did not obtain a GED while incarcerated and whose calendar quarters of entry into prison and forecasted release quarter from prison were the same as that of at least one GED holder.

Using information on all movements of individuals in the Florida Department of Corrections system we are able to construct distinct prison spells for each individual based on the date of incarceration for a new commitment and the date of prison release. ${ }^{10}$ In analyzing the impact of the GED on the post-release outcomes of offenders, there is a defining spell for GED holders that we call the "target spell," defined as the prison spell in which the GED holder obtained his credential. The years and quarters in which all observed target spells began formed the basis for searching the data base for uncredentialed dropouts who entered prison at approximately the same times. ${ }^{11}$

We will employ two different comparison groups in order to answer our two different research questions. The first group is composed of offenders who entered prison without a high school diploma and who either attempted but failed the GED exams or who took GED preparation classes but never attempted the GED exams. For expositional convenience we will call this group the GED "failers" even though a substantial portion of this group never attempted

\footnotetext{
${ }^{10}$ Our spells begin upon entry to jail for an eventual prison spell. Specifically, we impute a spell beginning date using prison entry date minus jail credit days. In our definition a spell must last more than one day and a spell is assumed to continue until a permanent release that lasts for more than one day is observed. If there is a subsequent entry into prison for that individual, a second spell begins and ends according to the same guidelines.

${ }^{11}$ We analyze one spell per individual, selecting the earliest one (if any) where there was at least one GED holder who entered prison in the same calendar quarter and had the same prison sentence length (rounded to half-years).
} 
the GED exams. Comparisons between GED passers and the dropouts in this "failing" group approximate the signaling value of the GED on post-release earnings. We note that to the extent that the GED passers acquire more prison-related human capital than the failers, contrasts between these groups will, of course, overstate the signaling value of the GED.

A second comparison group is composed of offenders who entered prison without a high school diploma and who were never enrolled in any GED preparation courses. These are the GED program non-participants. A third potential comparison group we could use is offenders who entered prison with a high school diploma. All preliminary investigations of the data indicate that GED holders (and all other dropout offenders) had consistently worse outcomes than did regular high school graduates, both before prison entry and upon release from prison. This matches what Cameron and Heckman (1993) and others have found for "free world" GEDs when compared to regular high school graduates. As a result we focus in this paper on comparisons between offenders who obtain a GED while in prison and the two comparison groups of dropout offenders who do not obtain a GED while incarcerated.

Social Security Numbers (SSNs) were used to link the Florida DOC data to the UI earnings data. All SSNs in our data were verified by programmers at the federal Social Security Administration based on standard verification algorithms used by the Employment Verification Service that matched DOC data on the digits of the SSN, date of birth, sex, and name to SSA records with some tolerance for clerical error. As might be expected in data on criminal offenders, about 19 percent of the sample lacks a valid SSN. Individuals with non-valid SSNs are more likely to be minority, a non-Florida resident, and unemployed at the time of arrest. Slightly over 20 percent of the potential non-attempting dropouts have non-valid SSNs, while only 15 to 
16 percent of the other three groups (GED passers, GED failers, and high school graduates) have non-valid SSNs.

\section{Analytical Methods}

Our analyses will primarily be concerned with measuring post-release quarterly earnings as measured by Unemployment Insurance (UI) wage records and post-release employment as inferred by non-zero UI quarterly earnings. Since UI earnings are recorded quarterly, we account for time in calendar quarters. Previous research has analyzed outcomes using time since actual release from prison as the post-release time metric. However, our regression models below are specified in terms of covariates and constructs of time that are known at the time the prison spell begins. Because of the ability of prisoners to affect their release date through "good behavior" and program participation, actual release date is endogenous, and not pre-determined. We address this issue by measuring release time relative to the forecasted release date, rather than time relative to when the offender was actually released. While this issue is important in principle, we find in practice that GED recipiency has little association with the deviation of actual release date from forecasted release date, and consequently the use of forecasted versus actual release dates has little impact on our results. ${ }^{12}$

We use three definitions of time in our analysis. Time in quarters relative to the start of an individual's target incarceration spell is indexed by "s" and we refer to it as "s-time". For example, $s=-1$ refers to the calendar quarter before the entry of an individual to their target spell in prison. Time relative to the forecasted release date of an offender based upon sentencing

\footnotetext{
${ }^{12}$ Offenders who leave prison with a GED and those who never take any GED courses spend on average about a month and a half longer in prison than their forecasted release date would predict, while offenders who take GED courses but do not obtain the credential spend about two months longer than their predicted sentence.
} 
information in our data is indexed by " $r$ " and we refer to it as "r-time." For example, $r=1$ refers

to the calendar quarter after the forecasted release date of an offender from prison. We index the quarter of actual release by "t", and refer to it as "t-time." Some of our regression analyses pool data from s-time and r-time, such as the four quarters before incarceration and the four quarters after forecasted release. We use these two concepts of time because we believe it is more meaningful for analysis of pre-prison outcomes to pool results around the beginning of incarceration and for analysis of post-prison outcomes to pool results around the time of forecasted release date -- rather than having a single anchor point in time. ${ }^{13}$

Our empirical analyses focus on post-release labor market outcomes. We will compare the post-release outcomes of offenders who obtain a GED while in prison relative to the post-release outcomes of the two dropout comparison groups. While we have no clear source of exogenous variation in GED status in these data, we do have a substantially richer set of available covariates to bring to the analysis than previous studies, and the longitudinal UI earnings data allow us to fit models that control for individual, time-invariant fixed effects. We use the following variable definitions:

- $\quad Y_{i t}=$ quarterly UI earnings for individual $i$ in time (year and quarter) $t .^{14}$

\footnotetext{
${ }^{13}$ To be concrete, consider individuals $\mathrm{X}$ and $\mathrm{Y}$ who entered prison at the same time and who have forecasted sentence lengths of 8 quarters and 16 quarters, respectively. Analysis in s-time is most useful for pre-prison outcomes. At $\mathrm{s}=-2$, both offenders have not yet begun their incarceration spell, so we can meaningfully compare their pre-prison outcomes. Pooling results on post-spell outcomes at time $\mathrm{s}=10$ is not very meaningful because $\mathrm{Y}$ will likely still be in prison. Analysis in $r$-time is most useful for post-prison outcomes. At $r=2$, it is likely that both offenders will have recently re-entered mainstream society, so we use r-time for post-spell analyses pooling individuals in $\mathrm{r}$-time. At $\mathrm{r}=-10, \mathrm{X}$ is not in prison, but $\mathrm{Y}$ is in prison so the pre-prison outcome is not observed. ${ }^{14}$ UI earnings are not available for out-of-state earnings or for jobs that are not usually covered by the UI system, such as self-employment, work which may be "off the books" such as domestic service or informal child care, or for employers who do not report earnings. Thus, UI earnings may understate "true" earnings. A comparison of data from UI and data with more complete coverage from the Social Security Administration (SSA) found that average earnings from SSA data were about 25\% higher. Self-reported earnings for adult men were $30 \%$ higher than UI reports, with the additional difference apparently due mainly to uncovered jobs rather than out-of-state jobs; in an evaluation of JTPA training, the differences between the treatment and control groups were similar for survey and
} 
- $G E D_{i}=\mathrm{a}(0,1)$ indicator for whether individual $i$ obtained a GED while incarcerated.

- $A G E=$ a set of two variables containing age and age squared when $Y$ is measured.

- $\quad Y R Q T R=$ a set of dummies for the year and quarter in which $Y$ is measured.

- $X_{i}=$ a set of covariates that includes:

-- EDUC (a set of indicators for years of completed schooling),

-- predicted sentence length,

-- marital status and number of dependents upon prison spell entry,

-- years in Florida prior to prison spell,

-- whether or not a Florida resident at prison entry,

-- state or region of birth,

-- whether or not employed prior to arrest and conviction,

-- industry and occupation of employment prior to arrest and conviction,

-- whether or not an English speaker,

-- whether or not a confirmed U.S. citizen or alien,

-- cumulative years in prison prior to the target spell,

-- number of disciplinary reports ever accumulated in prison prior to the target spell,

-- type of offense for target spell in prison, and

-- a measure of cognitive skills at beginning of the target spell ${ }^{15}$

A regression model for the simplest model of mean differences between GED and non-GED

holders is given in equation 1.

$$
Y_{i t}=\beta_{1}+G E D_{i t} \delta_{1}+\varepsilon_{1 i t}
$$

To match the typical model found in the literature on prison-based interventions the first regression adjusted estimating equation we employ is:

$$
Y_{i t}=\beta_{20}+G E D_{i t} \delta_{2}+A G E_{i t} \beta_{21}+Y R Q T R_{i t} \beta_{22}+E D U C_{i} \beta_{23}+\varepsilon_{2 i t}
$$

UI employment rates, suggesting that between group differences may remain quite informative even when levels differ (Kornfeld and Bloom 1999).

${ }^{15}$ The measure of cognitive skills that we employ is the Test of Adult Basic Education (TABE). The first stop for offenders entering the Florida prison system is the "reception center" where they are processed. While at the reception center, all offenders are administered the Survey test battery of the TABE. This test is particularly appropriate for our use since it is administered before any prison interventions. Since different versions of the TABE tests were administered during the period we cover, and since TABE scores are not necessarily equitable across versions, we created a vector of $58 \mathrm{TABE}$ score by version indicators. We control for TABE scores with this vector of indicators. 
where $i$ indexes person. We fit equation 2 on a stacked four quarters of $r$-time earnings data: $r=1$ through $r=4$ in one instance, $r=5$ through $r=8$ next, and then $r=9$ through $r=12$. This allows us to estimate $\delta_{2}$ for the $1^{\text {st }}, 2^{\text {nd }}$, and $3^{\text {rd }}$ year after the forecasted release date. Using Ordinary Least Squares (OLS), we fit equation 2 separately for the two different comparison groups. We also fit separate models for white offenders and minority group offenders. Estimates of $\delta_{2}$ provide estimates of the average difference in quarterly earnings between GED holders and uncredentialed dropouts in (respectively) the first, second, and third years after prison release, depending on what r-times are used.

In a third model we include the other control variables described above, bringing to bear considerably more information than has heretofore been used in studying prison-based education programs. Equation 3 illustrates the additional variables,

$$
Y_{i t}=\beta_{30}+G E D_{i t} \delta_{3}+A G E_{i t} \beta_{31}+Y R Q T R_{i t} \beta_{32}+X_{i} \beta_{33}+\varepsilon_{3 i t}
$$

where $X$ contains the variables discussed above that are not in EDUC, AGE, or YRQTR.

Equation 3 offers substantial advantages over prior research on prison education programs since it utilizes the rich set of control variables available in our Florida data. We can, however, use longitudinal nature of the UI earnings data to push the analysis a step further by estimating the fixed effects model of equation 4 :

$$
Y_{i t}=A F T_{i t} \beta_{40}+G E D_{i t} \delta_{4}+A G E_{i t} \beta_{41}+Y R Q T R_{i t} \beta_{42}+A F T_{i t} * X_{i} \beta_{43}+\alpha_{i}+\varepsilon_{4 i t}
$$

Equation 4 is fit using pre-spell earnings or employment data from quarters $s=-4$ through $s$ $=-1$ stacked with post-release earnings: $r=1$ through $r=4$ in one instance, $r=5$ through $r=8$ in a second estimation, and $r=9$ through $r=12$ in a third estimation. A time-invariant, fixed effect for each individual is captured in $\alpha_{i}$. In this setting the variable $A F T$ equals zero in the s-time quarters and one in the r-time quarters, and it captures the main effect of being in the labor 
market in post-release period relative to the period before prison entry. The interaction of $A F T$ and $X$ essentially allows main effects of $X$ in the regression for changes in the outcome within individuals over time. ${ }^{16} G E D$ in equation 4 equals zero for everyone in s-time, switching to one in r-time for those who obtained a prison-GED. In computing standard errors in all three models, we account for dependence of the errors within persons, across time.

We also considered using a regression discontinuity design to study the impact of a prisonGED, since a sharp cutoff on GED test scores determines who does or does not obtain a GED. Our discussions with Florida Department of Corrections officials who administer the GED program suggest, however, that such a design could yield upwardly biased estimates of the impact of the GED. Inmates in Florida are widely discouraged from taking the GED exams until there is a very good chance, based on scores on GED practice exams, that they will achieve a passing score. Given this severe screening on who takes the GED exams in Florida's prisons, we believe that the five percent who do take the exams without passing are not comparable to those above the passing threshold, even after controlling for the linear component of the GED test score. $^{17}$

${ }^{16}$ For example, if there were one observation of the outcome before prison and one after, an interaction of AFT and $X$ in a fixed effects model would control for changes in the outcome related to time invariant characteristics like type of conviction offense. Time varying coefficients for time invariant characteristics has also been used by Jacobson, Lalonde, and Sullivan (1993) in the context of evaluating the effect of job loss on later earnings and Ashenfelter and Hyslop (2001) in measuring the effects of arbitration on wages.

17 This policy is reflected in the fact that of all the individuals in our data with a record of ever taking the GED exams while in prison, only five percent never achieved a passing score. This compares with about a twenty five percent non-pass rate among free world GED candidates in Florida over the same period, based on our calculations using free world GED data from Florida. In regression discontinuity estimates we do find that offenders who score just above the passing threshold, and obtain a GED, have quarterly earnings by the second year that are a statistically significant \$400 greater than those who score just below the threshold. However, we do not believe the conditions hold to interpret this as the causal impact of the GED. 


\section{Descriptive Statistics}

Table 1 compares basic descriptive statistics across GED holders and the two comparison groups in the earnings/employment sample. GED holders are substantially more likely to be white than are the two uncredentialed dropout groups. About 60 percent of the GED holders are white compared to roughly 45 percent in the two uncredentialed dropout groups. Mean years of completed schooling at prison entry are very similar across the groups, while GED passers and failers tend to be younger than the program non-participants who received no GED-related education while in prison.

In terms of criminal justice related factors, offenders who obtain a GED during the prison spell under study appear to be substantially more likely to have had a previous stay in prison (about 24 percent compared to 14 and 18 percent for the uncredentialed dropout groups). ${ }^{18}$ However, some portion of this difference is partly an artifact of the way we selected the two dropout comparison groups. Since for these individuals we used their first spell that matched a spell where there was also one GED holder, we do not include future spells they may have had in calculating this percentage. Offenders who obtained a GED while in prison had slightly more disciplinary reports on their records (9.7) than did dropouts with some prison-based GED education (5.6) and dropouts with no prison-based GED education (5.9). GED holders are more likely to be in prison this spell for a property offense and less likely to be in prison for a drugrelated offense, relative to the uncredentialed dropout groups.

Interestingly, GED failers has higher rates of participation in prison work release programs (24 percent) than either GED holders (20 percent) or dropouts (16 percent). Also, a higher

\footnotetext{
${ }^{18}$ While not shown here, conditional on having prior prison experience, GED holders spent longer amounts of time in prison prior to this spell than the other groups (about 450 days for eventual GED holders compared to about 380 days for the other dropout groups).
} 
percentage of GED failers spent some time in prison GED preparation programs ( 93 percent) than did offenders who took and passed the GED exams (68 percent). Meanwhile, offenders who obtained a GED while in prison participated in vocational training programs at higher rates than the two comparison groups. All groups had roughly similar participation rates in academic courses and work in prison industries.

In terms of variables related to the dependent variables that will be used in the analyses, there are essentially no differences in earnings or employment prior to entry into this prison spell. In the post-release period, GED holders have a higher probability of being employed than does the dropout group who received no GED-related education while in prison (44 percent versus 37 percent), and they have higher mean quarterly earnings one year after release $(\$ 1,200$ versus \$982). Meanwhile, the GED failers have post-release employment and earnings figures that lie between those of the GED holders and the no-education group of dropouts.

Though the differences are small, comparisons across groups in the last rows of Table 1 are consistent with a hypothesis that obtaining a GED is effective in improving the post-release outcomes of offenders. The fact that there are observable differences between offenders who obtain a GED while in prison and those who do not cautions against making too much of the raw earnings and employment differences. In some instances GED holders have average characteristics that would lend an advantage in the labor market. In particularly, they are more likely to be white. In terms of criminal justice outcomes, however, offenders who obtain a GED look less favorable. They were more likely to have had a prior stay in prison and that stay was longer, they tend to have more disciplinary reports on their record, and they are more likely to 
have committed property crimes. ${ }^{19}$ The empirical analyses that follow attempt to account for these and other potential differences between dropout offenders who do and do not obtain a GED while in prison.

Figures 1-3 display mean quarterly earnings around the time of release based on t-time (Figure 1), r-time (Figure 2), and s-time (Figure 3). In these figures we include offenders who entered prison with a regular high school diploma to illustrate the fact that these offenders have substantially different outcomes than do dropout offenders with or without a prison-based GED. In Figures 1 and 2 the zero quarter represents the release quarter. In Figure 1 this represents the quarter in which individuals were actually released from prison, while in Figure 2 this represents the forecasted release date quarter. The patterns in these two graphs are roughly similar.

Figures 1 and 2 indicate that even during quarters when most individuals are in prison (ttime and r-time just before zero), there are non-zero quarterly earnings. Non-zero earnings during prison result primarily from employment emanating from prison work release centers. For example, about 17 percent of the offenders in our data were in work release centers at $r=-1$, working an average of 67 days during that quarter.

Figure 3 shows that the earnings of all dropout groups are substantially lower than the prespell earnings of high school graduates. Also in Figure 3, the pre-target spell earnings of all dropout groups are similar, offering some evidence that there are no substantial "pre-treatment" differences between those who will and will not obtain a prison GED. An implication of this fact is accounting for earnings prior to prison (as in our fixed effects model in equation 4) will have little impact on GED coefficients. Our hypothesis that GED program participants would have

\footnotetext{
${ }^{19}$ Steurer, Smith, and Tracey (2001) also found that offenders who obtain prison-based educational programming look somewhat worse on some criminal justice-related measures than offenders who received no educational programming while in prison.
} 
higher earnings prior to participation than other dropouts was not confirmed, suggesting that the selection process of GED participation was not simply one in which those with better labor market prospects were also those that participated.

Figures 1 and 2 offer, at best, weak evidence that dropouts who earned a GED while in prison have post-prison spell earnings that are different from dropouts who do not leave prison with a GED. Figures 1 and 2 do not, however, account for the role played by observable factors that may affect earnings and the other outcomes of interest.

\section{Results}

We first discuss results from a model that most closely resembles models used in prior research on the effectiveness of prison-based education programs, and we examine what happens to these estimates across specifications with increasing controls for observable factors. The most naïve estimates of the "effects" of prison-based education programs in the literature simply compare program participants and non-participants. In this spirit, our naïve estimates compare all offenders who leave prison with a GED, to those who do not, pooling all uncredentialed dropouts together, both the GED failers in our data and those who did not participate in some GED-related education while in prison. Estimates from this rudimentary specification, our equation 1, are in the first column of Panel A in Table 2, and they indicate that in the first year GED holders have mean quarterly earnings that are $\$ 181$ higher than uncredentialed dropout offenders. The GED advantage is $\$ 180$ in the second year, $\$ 109$ in the third year, and all three estimates are statistically significant. ${ }^{20}$ These mean earnings estimates are similar to the estimates for

\footnotetext{
${ }^{20}$ While simplistic from the point of view of estimating the effect of a GED for an individual, these results may be relevant from the point of view of an employer with little information (say, only dropout and conviction status) trying to infer the expected productivity of GED and non-GED holders.
} 
participation in prison education programs by Steurer, Smith and Tracy (2001) discussed earlier, including the pattern of decreasing differences in the third year.

The first innovations we bring to the topic are to allow differential GED effects for white and minority group members. The second and third columns of Panel A suggest that estimated mean differences based on a pooled sample, as in the first column, mask differential GED effects by race/ethnicity. Only the first year estimates in Panel A are statistically different for white and minority dropouts. The point estimate for minority group members in the second year is, however, twice as large as the estimate for whites and so we will continue to explore differences by race/ethnicity in the analyses that follow. Another reason for displaying results by race/ethnicity is an exploration of the declining GED "effects" in the third year for minority group seen in Panel A.

Panel B of Table 2 presents results from equation 2 . The results here indicate that the naïve estimates of Panel A are little changed by adding controls for basic characteristics such as age and education level. We continue to find the only statistically significant results for minority offenders in the results on stratified samples in columns 2 and 3, and it is only the first year estimates of the GED earnings advantage that is statistically different by race. ${ }^{21}$

The second innovation we bring to this line of research is our ability to include a much richer set of covariates than has heretofore been employed in research on prison-based education programs. OLS estimates from equation 3 are shown in Panel C of Table 2. The personal characteristics—including marital status, alien status, and state of residence and employment characteristics at the time of arrest—and prior criminal justice history that are controlled for in

\footnotetext{
${ }^{21}$ We test this hypothesis in a model that constrains the effects of the other independent variables to be the same for whites and minority group members. The p-value on the interaction between the GED indicator and a dummy variable indicator for being white is 0.056 in the first year regression.
} 
equation 3 substantially reduce the estimated GED earnings advantage between Panels B and C. Reductions in the GED earnings premium occur for both white and minority group offenders, except for the minorities' estimate in the second year after release where there is only a 10 percent reduction in the estimate from Panel B to Panel C ( $\$ 203$ to $\$ 180)$.

The third innovation we bring to this line of research is an ability to estimate models that control for individual fixed effects, as in equation 4. The estimates in Panel D of Table 2 indicate that once we control for the variables in the $X$ vector in equation 3, there is little to be gained from fixed effects estimation. The estimates in Panels C and D are similar across groups and years. $^{22}$

A first lesson from these estimates is that any credible research on the effects of prisonbased programs has to be able to control for more factors than has been the norm in this line of research. The inclusion of the additional covariates in the $X$ vector of equation 3 drives the naïve estimates in column 1 to close to zero. Nevertheless, even with the richer control variable set, we continue to estimate differences between GED holders and all uncredentialed dropouts among minority offenders. Thus, a second lesson is that research on prison-based programs should pay attention to the possibility that estimated program effects may be different for white and minority offenders. Remarkably, within the minority group there is little difference between the results that control for nothing in panel A and the results that control for a rich set of covariates and fixed effects in panel D.

Results in Table 2 allow for an examination of naïve estimates of correctional education programs compared to what one would estimate allowing for differential effects by race/ethnicity

\footnotetext{
${ }^{22}$ Comparing panel C to panel D, the point estimates increase slightly. The reason for this is that the regressionadjusted GED coefficient for the four quarters prior to the beginning of the prison spell (using equation 3 ) is insignificant but negative in sign. Conditional on observable Xs, GED holders had slightly lower earnings prior to prison.
} 
and controlling for important observable differences between treatment and comparison group individuals. These results allow one to judge the results from typical prison education research relative to what one would find when sets of desirable control variables are included. Our primary interest, however, is answering our two research questions. First, what is the impact on subsequent earnings of obtaining a GED relative to not having a GED program in prison at all? And second, is there value in actually obtaining the GED credential while in prison beyond effects of preparing for the exam itself? The estimates in Table 3 bring information to bear on these questions.

The entries in the first two columns of Table 3 contrast the post-release quarterly earnings of offenders who obtained a GED to those of dropout offenders who did not participate in any GED preparation classes. In the ideal, the comparison group here estimates the counterfactual of what would have been the earnings of GED holders if there had been no prison GED program.

Estimates in column 1 of Panel A show no measurable differences between the unadjusted earnings of white GED holders and white dropouts with no prison-based secondary education. Meanwhile, the simple contrasts among minority group members (column 2) show that GED holders earn about $\$ 220$ - $\$ 260$ more per quarter in the first two years after release, but that this earnings advantage falls off sharply and approaches zero in the third post-release year. These same basic observations hold as we move down columns 1 and 2 through the different specifications. In particular, even the fixed effects estimates in Panel D are relatively similar to the unadjusted estimates of Panel A, showing no GED benefits for whites, and a GED earnings advantage of around $\$ 200$ for minorities in the first two post-release years, falling to almost and statistical insignificance in the third post-release year. Thus, the estimates for the minority group 
are not diminished very much even after controlling for a rich set of covariates and for fixed effects.

The overarching story of the first two columns is that determining the value of a prison GED program depends highly on the group used to evaluate that question. It appears that white offenders have little to gain from a prison-based GED program; there are no statistically significant earnings differences by GED status and all of the point estimates are relatively small in magnitude. Meanwhile, minority group members who obtain a GED show consistently higher post-release earnings than minority dropout offenders with no prison-based GED-related education in the first two post-release years, an earnings advantage that consistently falls to near zero after the second year. $^{23}$

We note that other work on the returns to a free world GED has found that all of the impact is at the bottom end of the skill distribution: the GED seems to have large earnings effects for the least skilled dropouts and none for high skilled dropouts (Tyler 2003). Using TABE test scores and TABE test versions to construct several different definitions of "low skilled" and "high skilled" dropouts, we do not find a similar pattern of differential GED effects by skill level for prison GEDs.

Entries in columns 3 and 4 of Table 3 bear on the question of the additional value of obtaining a prison-based GED once you have participated in prison secondary education programs. These estimates compare the post-release quarterly earnings of the same GED holders used in columns 1 and 2 to dropout offenders who participated in correctional GED programs but who left prison without the credential. Fourteen percent of the comparison group attempted, but failed, the GED exams, while the other 86 percent never attempted the exams during their time in

\footnotetext{
${ }^{23}$ In the fixed effects estimates of Panel D, it is only in the first year that the minority group results are statistically different from the results estimated over whites.
} 
prison. A common reason for having GED course hours but no record of attempting the GED exams is that the inmate has not achieved literacy and numeracy skill levels that would give a reasonable expectation of passing the GED exams at the time of their release from prison. To the extent that the GED coefficient in this analysis is positive, it will in principle contain both the signaling value of the GED as well as the additional human capital that GED holders garner relative to offenders who study for but do not obtain a GED while in prison. Results not shown in the table indicate that there is little relationship between GED test score and subsequent earnings among GED holders, however, so we infer that the GED coefficients in columns 3 and 4 primarily represent a signaling effect.

Even though we expected lower average skills in the comparison group than among GED holders, the estimates in columns 3 and 4 of Table 3 provide no consistent evidence of postrelease earnings differences between the two groups. In particular, the set of estimates for white offenders indicate no substantive or statistically significant GED earnings advantage. The fixed effects estimates for minority offenders yield the only evidence that GED holders fare better than offenders who obtain some prison based education, but no GED credential. The second year estimate for minority offenders is about as large as the second year estimate for minority offenders in column 2 , and it is marginally statistically significant.

\section{Conclusion}

The convergence of two trends has made an understanding of prison-based interventions such as the GED increasingly important. At the same time that low skilled individuals are facing increasingly dim economic prospects, there has been a dramatic increase in the U.S. prison population driven primarily by the incarceration of low skilled males. The result is a historically 
large proportion of inmates who, upon release, will face steep obstacles as they try to reintegrate into the mainstream labor market. A primary vehicle used to help prepare offenders for reentrance into society and the mainstream labor market has been the corrections-based GED program. In spite of the wide spread use of this program, however, there has been scant research on how effective it actually is in meeting the desired goals. Past research showing positive benefits of corrections-based education programs has been less than convincing, often because of inappropriate data. We utilize a unique and particularly rich data set on individuals who were in Florida prisons during the 1990s to produce the following main findings on one of the most important prison education programs, the GED

1. There is virtually no evidence that the earnings of white GED holders are higher than the post-release earnings white dropout offenders without a GED. This is true when the comparison is made against dropouts who have and have not had any prisonbased secondary education.

2. There is some evidence that having a GED program benefits minority offenders. When compared to minority offenders who never participated in GED-related education, minority group offenders with a GED had quarterly earnings that were approximately $\$ 200$ higher in the first two years after release from prison. This represents about a 20 percent increase in earnings.

3. There is very little evidence that, conditional on participating in GED-related education, there is extra benefit to actually acquiring the credential.

4. Any benefits that accrue to minority offenders from obtaining a GED appear to fade substantially after the second year. 
The two most robust findings are the racial/ethnic differences in any returns to a prison GED and the fall off in any GED benefits for minority offenders after the second year. Both results show up in the point estimates of virtually all models and regardless of the samples used in the estimation. Participation in education programming may be driven more by a desire to impress prison and parole officials and improve one's situation in prison than by a desire to impact one's post-release labor market outcomes. ${ }^{24}$ To the extent that this is the case in our Florida data, and to the extent that this rationale for participation in prison-based education programming is more prevalent among white offenders, this could help explain the differential results we see by race/ethnicity. Unfortunately there is no information in our data that would allow us to explore this possibility.

The virtual disappearance of any GED effect between the second and third years after release for minority offenders is also puzzling. In analysis not shown here but available from the authors, we use a smaller sample of offenders for whom we have 16 full quarters of post-release earnings data. The downward trend of the estimated GED effect on the earnings of minority offenders also appears in year three in these data and continues to diminish in year four after release. In trying to understand this puzzling trend we can rule out differential recidivism rates and post-release community supervision rates as possible explanations since separate analyses not shown in this paper show no effects of a prison GED on either recidivism or post-release

\footnotetext{
${ }^{24}$ Possible explanation for race-based differences in any GED effects is suggested in the work of Steurer, Smith, and Tracey (2001). In a survey they administered to offenders just prior to release in 1997-1998, they find that relative to offenders with no prison-based educational programming, offenders who had participated in education programs while in prison reported a consistently lower motivation in regard to several labor market activities including the "motivation to get a job, a better job, or higher pay" or the "motivation to improve job performance." While none of the differences between those who did and did not participate in prison education were statistically significant (at the 0.01 level), the point estimates consistently pointed to a negative correlation between prison-based education participation and labor market motivation. On the other hand, offenders in the Steurer et al. study who participated in prison-based education programs indicated a higher motivation to both "look good to prison or parole officials to get out" and to "get a better situation in prison" than did offenders who did not participate in education programming while in prison.
} 
community supervision. ${ }^{25}$ Regarding the downward trend in the GED earnings effect, we can only note at this point that the same downward trend, after initial positive effects, was found by Steurer, Smith and Tracy (2001), and is a result worthy of further study.

While we find evidence of a short-term GED impact on earnings for minority offenders, we also note that participation in prison-based GED programs may generate non-economic benefits that we have not examined. ${ }^{26}$ Also, it could be that obtaining a GED confers post-release benefits that are not directly connected to the labor market such as the ability to be a better parent or more effectively engage in the civic life of the free world. Were this systematically the case, however, one would expect GED holders to recidivate at lower rates, something we did not find. In short, there may be advantages to corrections-based GED programs not examined in this paper.

Our data contain no clear source of exogenous variation in GED status. This is particularly problematic in a prison setting where there are fierce selection issues at both the administrative and the individual level. We try to address heterogeneity issues as best we can by using both an unusually rich data set on criminal justice offenders and by fitting fixed effects models that control for time invariant heterogeneity. We do think that the fixed effects estimates in this paper represent the most vigorous attempt to date to obtain good estimates of the impact of obtaining a GED while in prison on later outcomes. Nevertheless, since we have no transparent manner of controlling for potential time-varying heterogeneity, caution should be exercised in attaching causal inferences to our estimates.

\footnotetext{
${ }^{25}$ In this analysis we define recidivism as being convicted of a crime within three years of the forecasted release date that results in a return to prison or probation,

${ }^{26}$ For example, security considerations are of paramount importance in correctional institutions, and it could be that participation in a GED preparation program leads to better behavior while incarcerated. While this is possible, we did not find that GED program participants in our data had fewer disciplinary reports during the target spell than did the comparison groups. Still, given the importance of security issues, this is an area that deserves a closer look.
} 


\section{REFERENCES}

Ashenfelter, Orley, and Dean Hyslop. 2001. "Measuring the Effect of Arbitration on Wage Levels: The Case of Police Officers." Industrial and Labor Relations Review January, 54, no. 1, 316-328.

Becker, Gary S. 1993. Human Capital: A Theoretical and Empirical Analysis with Special Reference to Education. Chicago: The University of Chicago Press.

Blumstein, Alfred, and Allen J. Beck. 1999. "Population Growth in U.S. Prisons, 1980-1996." In Crime and Justice: Prisons. (Volume 26.) Edited by Michael Tonry and Joan Petersilia. 17-62.

Boudett, Kathryn Parker. 2000. "'Second Chance' Strategies for Women Who Drop Out of School." Monthly Labor Review December, 19-31.

Bureau of Justice Statistics. 2003. (NCJ 198272) "Census of State and Federal Correctional Facilities, 2000," Washington, DC: U.S. Department of Justice.

Cameron, Stephen V. and James J. Heckman. 1993. "The Nonequivalence of High School Equivalents." Journal of Labor Economics 11, no. 1, 1-47.

Heckman, James J., Jingjing Hsse, and Yona Rubinstein. 2000. "The GED is a 'Mixed Signal': The Effect of Cognitive and non-Cognitive Skills on Human Capital and Labor Market Outcomes." Unpublished manuscript, University of Chicago.

Kornfeld, Robert and Howard Bloom. 1999. "Measuring Program Impacts on Earnings and Employment: Do Unemployment Insurance Wage Records Agree with Survey Reports of Individuals?" Journal of Labor Economics 17, no. 1, 168-197.

Jacobson, Louis S., Robert J. Lalonde, and Daniel G. Sullivan. "Earnings Losses of Displaced Workers." American Economic Review 83, no. 4, 685-709.

Mauer, Marc. 1999. Race to Incarcerate. New York: Free Press.

Murnane, Richard J., John B. Willett, and Kathryn Parker Boudett. 1999. "Do Male Dropouts Benefit from Obtaining a GED, Postsecondary Education, and Training?" Evaluation Review 22, no. 5, 475-502.

Murnane, Richard J., John B. Willett, and John H. Tyler. 2000. "Who Benefits from a GED? Evidence from High School and Beyond." The Review of Economics and Statistics 82, no. 1, 23-37.

Sampson, R.J. and J.H. Laub. 1993. Crime in the Making: Pathways and Turning Points through Life. Cambridge, MA: Harvard University Press. 
Spence, Michael. 1973. "Job Market Signaling." Quarterly Journal of Economics 87, 355-374.

Steurer, Stephen, Smith, Linda and Tracy, Alice. 2001. "Three State Recidivism Study." Report for the Office of Correctional Education, United States Department of Education.

Thornberry, T.P. and R.L. Christenson. 1984. "Unemployment and Criminal Involvement: An Investigation of Reciprocal Causal Structures." American Sociological Review 49, 398411.

Tyler, John H. 2003. "The Economic Benefits of the Ged: Lessons from Recent Research." Review of Educational Research. 73, no. 3, pp. 369-403.

Tyler, John H. 2001. "So You Want a GED? Estimating the Impact of the GED on the Earnings of Dropouts." Brown University Department of Economics Working Paper No. 01-34.

Tyler, John H., Richard J. Murnane, and John B. Willett. 2000. "Estimating the Labor Market Signaling Value of the GED." Quarterly Journal of Economics CXV, no. 2, 431-468.

Western, Bruce and Becky Pettit. 2000. "Incarceration and Racial Inequality in Men's Employment." Industrial and Labor Relations Review 54, 3-16.

Wilson, David B., Catherine A. Gallagher, Mark B. Coggeshall, and Doris L. MacKenzie. 1999. "A Quantitative Review and Description of Corrections-Based Education, Vocation, and Work Programs." Corrections Management Quarterly 3, no. 4, 8-18.

Wilson, David B., Catherine A. Gallagher, and Doris L. MacKenzie. 2000. "A Meta-Analysis of Corrections-Based Education, Vocation, and Work Programs for Adult Offenders." Journal of Research in Crime and Delinquency 37, no. 4, 347-368.

Zamble, E. and F.J. Porporino. 1988. Coping, Behavior, and Adaptation in Prison Inmates. New York: Springer-Verlag. 
Table 1

Descriptive statistics

\begin{tabular}{|c|c|c|c|}
\hline & $\begin{array}{l}\text { Dropouts who } \\
\text { leave prison with } \\
\text { a GED }\end{array}$ & $\begin{array}{l}\text { Uncredentialed } \\
\text { GED "failers" }\end{array}$ & $\begin{array}{c}\text { Uncredentialed } \\
\text { dropouts offenders } \\
\text { with no GED-related } \\
\text { education } \\
\end{array}$ \\
\hline $\mathrm{N}$ & 1,967 & 1,400 & 9,589 \\
\hline$\%$ white & 60 & 47 & 45 \\
\hline$\%$ black & 32 & 45 & 46 \\
\hline \% Hispanic & 7 & 7 & 8 \\
\hline$\%$ other race & 0.3 & 0.5 & 0.3 \\
\hline mean years education & $\begin{array}{c}9.7 \\
(1.3)\end{array}$ & $\begin{array}{c}9.5 \\
(1.3)\end{array}$ & $\begin{array}{c}9.5 \\
(1.4)\end{array}$ \\
\hline mean age at admission & $\begin{array}{l}25.6 \\
(8.0)\end{array}$ & $\begin{array}{l}25.0 \\
(7.5)\end{array}$ & $\begin{array}{l}29.4 \\
(9.2)\end{array}$ \\
\hline$\%$ age $18-20$ at admission & 28 & 31 & 15 \\
\hline$\%$ age $21-25$ at admission & 28 & 31 & 24 \\
\hline$\%$ age $26-30$ at admission & 15 & 12 & 18 \\
\hline$\%$ age $31-35$ at admission & 11 & 10 & 16 \\
\hline$\%$ age $36-40$ at admission & 7 & 6 & 13 \\
\hline$\%$ age over 40 at admission & 6 & 5 & 12 \\
\hline $\begin{array}{l}\% \text { with prior incarceration } \\
\text { spell }\end{array}$ & 24 & 13 & 18 \\
\hline $\begin{array}{l}\% \text { with prior disciplinary } \\
\text { report }\end{array}$ & 10 & 6 & 6 \\
\hline $\begin{array}{l}\% \text { with violent crime } \\
\text { offense this spell }\end{array}$ & 39 & 39 & 36 \\
\hline $\begin{array}{l}\% \text { with property crime } \\
\text { offense this spell }\end{array}$ & 41 & 37 & 36 \\
\hline $\begin{array}{l}\% \text { with drug } \\
\text { crime offense this spell }\end{array}$ & 16 & 21 & 24 \\
\hline $\begin{array}{l}\% \text { with other } \\
\text { crime offense this spell }\end{array}$ & 4 & 4 & 4 \\
\hline $\begin{array}{l}\% \text { participated in work } \\
\text { release program }\end{array}$ & 20 & 24 & 14 \\
\hline $\begin{array}{l}\text { mean days in work release } \\
\text { for participants }\end{array}$ & $\begin{array}{c}171 \\
(103)\end{array}$ & $\begin{array}{l}172 \\
(98)\end{array}$ & $\begin{array}{l}165 \\
(98)\end{array}$ \\
\hline $\begin{array}{l}\% \text { with hours in GED } \\
\text { classes this spell }\end{array}$ & 68 & 93 & 0 \\
\hline $\begin{array}{l}\% \text { with hours in vocational } \\
\text { training this spell }\end{array}$ & 28 & 19 & 10 \\
\hline $\begin{array}{l}\% \text { with hours in academic } \\
\text { classes this spell }^{\mathrm{a}}\end{array}$ & 28 & 27 & 29 \\
\hline $\begin{array}{l}\% \text { with hours working in } \\
\text { prison industry this spell }\end{array}$ & 3 & 2 & 3 \\
\hline
\end{tabular}




\begin{tabular}{lccc} 
mean sentence length in & 19.9 & 17.7 & 14.4 \\
months this spell & $(10.5)$ & $(9.6)$ & $(9.0)$ \\
$\%$ who recidivate within 1 & 17 & 16 & 16 \\
$\begin{array}{l}\text { year } \\
\text { \% who recidivate within } 2\end{array}$ & 26 & 27 & 25 \\
$\begin{array}{l}\text { years } \\
\begin{array}{l}\text { employed one year } \\
\text { before prison entry }\end{array}\end{array}$ & 32 & 32 & 31 \\
$\begin{array}{l}\% \text { employed one year after } \\
\text { release } \\
\text { quarterly wage one year } \\
\text { before prison entry } \\
\text { quarterly wage one year } \\
\text { after release }\end{array}$ & 44 & 41 & 37 \\
\hline
\end{tabular}

a. Represents non-GED-related academic coursework.

Notes. Sample standard deviations in parentheses. 
Table 2

Quarterly earnings of

GED holders vs. uncredentialed dropouts

\begin{tabular}{|c|c|c|c|c|}
\hline \multirow{5}{*}{$\begin{array}{l}\text { Panel A: } \\
\text { Controlling } \\
\text { NOTHING }\end{array}$} & $\begin{array}{l}\text { Years } \\
\text { after } \\
\text { release }\end{array}$ & $\begin{array}{l}\text { All } \\
(1)\end{array}$ & $\begin{array}{c}\text { Whites } \\
\text { (2) }\end{array}$ & $\begin{array}{c}\text { Minorities } \\
\text { (3) }\end{array}$ \\
\hline & $1^{\text {st }}$ & $181^{* *}$ & 55 & $243^{* *}$ \\
\hline & year & $(41)$ & (55) & $(63)$ \\
\hline & $\begin{array}{l}2^{\text {nd }} \\
\text { year }\end{array}$ & $\begin{array}{c}180^{* *} \\
(48)\end{array}$ & $\begin{array}{c}95 \\
(65)\end{array}$ & $\begin{array}{l}208^{* *} \\
(72)\end{array}$ \\
\hline & $\begin{array}{c}3^{\text {rd }} \\
\text { year }\end{array}$ & $\begin{array}{c}109^{* *} \\
(51)\end{array}$ & $\begin{array}{l}101 \\
(71)\end{array}$ & $\begin{array}{c}39 \\
(72)\end{array}$ \\
\hline \multirow{4}{*}{$\begin{array}{l}\text { Panel B: } \\
\text { Controlling } \\
\text { AGE } \\
\text { YRQTR } \\
\text { EDUC }\end{array}$} & $1^{\text {st }}$ & $161^{* *}$ & 9 & $214^{* *}$ \\
\hline & year & $(40)$ & (54) & (63) \\
\hline & $\begin{array}{l}2^{\text {nd }} \\
\text { Year }\end{array}$ & $\begin{array}{c}183^{* *} \\
(49)\end{array}$ & $\begin{array}{c}72 \\
(66)\end{array}$ & $\begin{array}{c}203^{* *} \\
(73)\end{array}$ \\
\hline & $\begin{array}{c}3^{\text {rd }} \\
\text { year }\end{array}$ & $\begin{array}{l}125 \\
(52)\end{array}$ & $\begin{array}{c}67 \\
(73)\end{array}$ & $\begin{array}{c}65 \\
(75)\end{array}$ \\
\hline \multirow{3}{*}{$\begin{array}{l}\text { Panel C: } \\
\text { Controlling } \\
\text { AGE } \\
\text { YRQTR } \\
\text { X }\end{array}$} & $\begin{array}{c}1^{\text {st }} \\
\text { vear }\end{array}$ & $\begin{array}{c}13 \\
(45)\end{array}$ & $\begin{array}{l}-87 \\
(58)\end{array}$ & $\begin{array}{c}121^{* *} \\
(71)\end{array}$ \\
\hline & $\begin{array}{l}2^{\text {nd }} \\
\text { Year }\end{array}$ & $\begin{array}{c}70 \\
(55)\end{array}$ & $\begin{array}{l}-16 \\
(74)\end{array}$ & $\begin{array}{l}180^{*} \\
(82)\end{array}$ \\
\hline & $\begin{array}{c}3^{\text {rd }} \\
\text { year }\end{array}$ & $\begin{array}{c}22 \\
(58)\end{array}$ & $\begin{array}{c}-9 \\
(80)\end{array}$ & $\begin{array}{c}26 \\
(85)\end{array}$ \\
\hline \multirow{3}{*}{$\begin{array}{l}\text { Panel D: } \\
\text { Controlling } \\
\text { AGE } \\
\text { YRQTR } \\
\text { X } \\
\alpha_{i}\end{array}$} & $\begin{array}{c}1^{\text {st }} \\
\text { year }\end{array}$ & $\begin{array}{c}57 \\
(50)\end{array}$ & $\begin{array}{l}-27 \\
(68)\end{array}$ & $\begin{array}{l}164^{* *} \\
(77)\end{array}$ \\
\hline & $\begin{array}{l}2^{\text {nd }} \\
\text { Year }\end{array}$ & $\begin{array}{l}114^{\sim} \\
(60)\end{array}$ & $\begin{array}{c}45 \\
(82)\end{array}$ & $\begin{array}{l}224^{*} \\
(88)\end{array}$ \\
\hline & $\begin{array}{c}3^{\text {rd }} \\
\text { year }\end{array}$ & $\begin{array}{c}69 \\
(63)\end{array}$ & $\begin{array}{c}58 \\
(87)\end{array}$ & $\begin{array}{c}72 \\
(90)\end{array}$ \\
\hline $\mathrm{N}$ & & 12,956 & 6,138 & 6,818 \\
\hline
\end{tabular}

Notes. Panels A, B, C, and D contain GED coefficient estimates $\delta_{1}, \delta_{2}, \delta_{3}$, and $\delta_{4}$ from equations 1,2 , 3 , and 4 respectively. All entries in column 1 are from models that also control for race/ethnicity. The dependent variable is quarterly earnings in 2002 dollars, including zeros. Standard errors are in parentheses, adjusted for clustering within individuals over time. ${ }^{\sim}=\mathrm{p}<0.10 ;{ }^{*}=\mathrm{p}<0.05 ;{ }^{* *}=\mathrm{p}<0.01$. 
Table 3

Quarterly earnings of GED holders vs.

GED-program non-participants and GED "failers," by race/ethnicity

\begin{tabular}{|c|c|c|c|c|c|}
\hline & \multirow[b]{2}{*}{$\begin{array}{l}\text { Years } \\
\text { after } \\
\text { release }\end{array}$} & \multicolumn{2}{|c|}{$\begin{array}{c}\text { Comparison to dropouts } \\
\text { with no GED-related } \\
\text { education }\end{array}$} & \multicolumn{2}{|c|}{$\begin{array}{l}\text { Comparison to GED } \\
\text { "failers" }\end{array}$} \\
\hline & & $\begin{array}{l}\text { Whites } \\
\text { (1) }\end{array}$ & $\begin{array}{l}\text { Minorities } \\
\text { (2) }\end{array}$ & $\begin{array}{l}\text { Whites } \\
\text { (3) }\end{array}$ & $\begin{array}{l}\text { Minorities } \\
\text { (4) }\end{array}$ \\
\hline \multirow{3}{*}{$\begin{array}{l}\text { Panel A: } \\
\text { Controlling } \\
\text { NOTHING }\end{array}$} & $\begin{array}{c}1^{\text {st }} \\
\text { year }\end{array}$ & $\begin{array}{c}58 \\
(56)\end{array}$ & $\begin{array}{c}259^{* * *} \\
(63)\end{array}$ & $\begin{array}{c}34 \\
(84)\end{array}$ & $\begin{array}{l}122 \\
(85)\end{array}$ \\
\hline & $\begin{array}{l}2^{\text {nd }} \\
\text { year }\end{array}$ & $\begin{array}{l}103 \\
(66)\end{array}$ & $\begin{array}{l}221^{* *} \\
(72)\end{array}$ & $\begin{array}{c}42 \\
(99)\end{array}$ & $\begin{array}{l}116 \\
(93)\end{array}$ \\
\hline & $\begin{array}{l}3^{\text {rd }} \\
\text { year }\end{array}$ & $\begin{array}{l}105 \\
(72)\end{array}$ & $\begin{array}{c}39 \\
(73)\end{array}$ & $\begin{array}{c}79 \\
(106)\end{array}$ & $\begin{array}{c}36 \\
(98)\end{array}$ \\
\hline \multirow{3}{*}{$\begin{array}{l}\text { Panel B: } \\
\text { Controlling } \\
\text { AGE } \\
\text { YRQTR } \\
\text { EDUC }\end{array}$} & $\begin{array}{l}1^{\text {st }} \\
\text { year }\end{array}$ & $\begin{array}{c}11 \\
(56)\end{array}$ & $\begin{array}{l}237^{* * *} \\
(64)\end{array}$ & $\begin{array}{l}-37 \\
(82)\end{array}$ & $\begin{array}{c}16 \\
(84)\end{array}$ \\
\hline & $\begin{array}{l}2^{\text {nd }} \\
\text { year }\end{array}$ & $\begin{array}{c}77 \\
(68)\end{array}$ & $\begin{array}{l}216^{* *} \\
(75)\end{array}$ & $\begin{array}{c}18 \\
(99)\end{array}$ & $\begin{array}{c}56 \\
(93)\end{array}$ \\
\hline & $\begin{array}{l}3^{\text {rd }} \\
\text { year }\end{array}$ & $\begin{array}{c}56 \\
(75)\end{array}$ & $\begin{array}{c}68 \\
(77)\end{array}$ & $\begin{array}{c}71 \\
(105)\end{array}$ & $\begin{array}{c}20 \\
(99)\end{array}$ \\
\hline \multirow{3}{*}{$\begin{array}{l}\text { Panel C: } \\
\text { Controlling } \\
\text { AGE } \\
\text { YRQTR } \\
\text { X }\end{array}$} & $\begin{array}{c}1^{\text {st }} \\
\text { year }\end{array}$ & $\begin{array}{l}-100 \\
(61)\end{array}$ & $\begin{array}{l}141^{\sim} \\
(77)\end{array}$ & $\begin{array}{l}-19 \\
(87)\end{array}$ & $\begin{array}{c}28 \\
(84)\end{array}$ \\
\hline & $\begin{array}{l}2^{\text {nd }} \\
\text { year }\end{array}$ & $\begin{array}{c}-5 \\
(74)\end{array}$ & $\begin{array}{l}190^{*} \\
(91)\end{array}$ & $\begin{array}{c}33 \\
(109)\end{array}$ & $\begin{array}{l}125 \\
(96)\end{array}$ \\
\hline & $\begin{array}{l}3^{\text {rd }} \\
\text { year }\end{array}$ & $\begin{array}{l}-28 \\
(83)\end{array}$ & $\begin{array}{l}-8 \\
(95)\end{array}$ & $\begin{array}{c}99 \\
(112)\end{array}$ & $\begin{array}{c}89 \\
(103)\end{array}$ \\
\hline $\begin{array}{l}\text { Panel D: } \\
\text { Controlling }\end{array}$ & $\begin{array}{l}1^{\text {st }} \\
\text { year }\end{array}$ & $\begin{array}{l}-26 \\
(71)\end{array}$ & $\begin{array}{l}176^{*} \\
(84)\end{array}$ & $\begin{array}{l}-28 \\
(96)\end{array}$ & $\begin{array}{c}98 \\
(96)\end{array}$ \\
\hline $\begin{array}{l}\text { AGE } \\
\text { YRQTR } \\
\mathrm{Y}\end{array}$ & $\begin{array}{l}2^{\text {nd }} \\
\text { year }\end{array}$ & $\begin{array}{c}71 \\
(84)\end{array}$ & $\begin{array}{l}228^{*} \\
(97)\end{array}$ & $\begin{array}{c}19 \\
(116)\end{array}$ & $\begin{array}{l}190^{\sim} \\
(109)\end{array}$ \\
\hline $\begin{array}{l}X \\
\alpha_{i}\end{array}$ & $\begin{array}{l}3^{\text {rd }} \\
\text { year }\end{array}$ & $\begin{array}{c}57 \\
(91)\end{array}$ & $\begin{array}{c}34 \\
(100)\end{array}$ & $\begin{array}{c}83 \\
(120)\end{array}$ & $\begin{array}{c}156 \\
(116)\end{array}$ \\
\hline $\mathrm{N}$ & & 5,475 & 6,081 & 1,849 & 1,518 \\
\hline
\end{tabular}

Notes. Panels A, B, C, and D contain GED coefficient estimates $\delta_{l}, \delta_{2}, \delta_{3}$, and $\delta_{4}$ from equations 1,2 , 3 , and 4 respectively. The dependent variable is quarterly earnings in 2002 dollars, including zeros. Standard errors are in parentheses, adjusted for clustering within individuals over time. ${ }^{\sim}=\mathrm{p}<0.10 ;{ }^{*}=$ $\mathrm{p}<0.05 ;{ }^{* *}=\mathrm{p}<0.01$. 
Figure 1

Raw earnings around the actual prison release quarter, by education

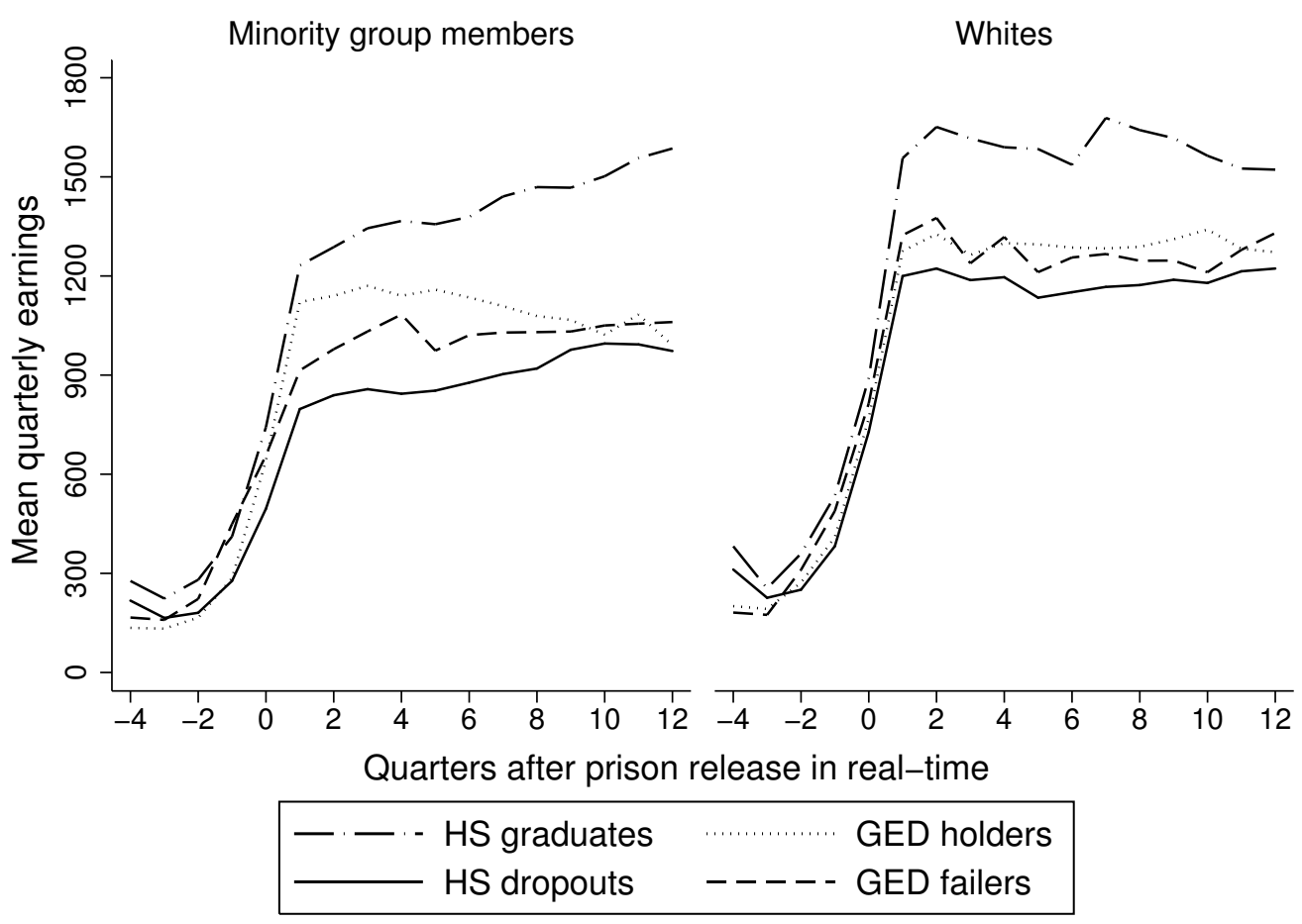

Figure 2

Raw earnings around the forecasted prison release quarter, by education

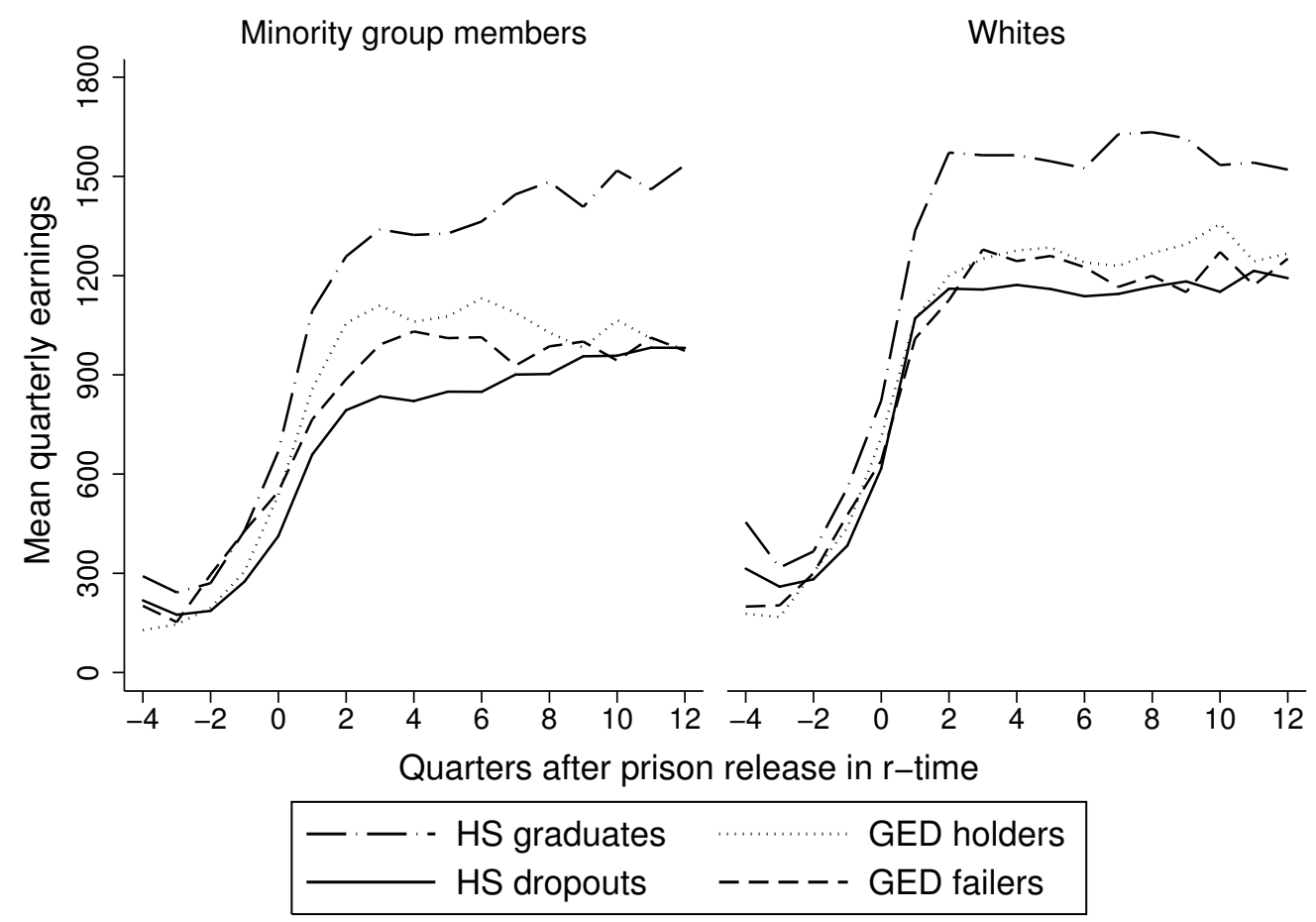


Figure 3

Raw earnings profiles around the prison entry quarter, by education

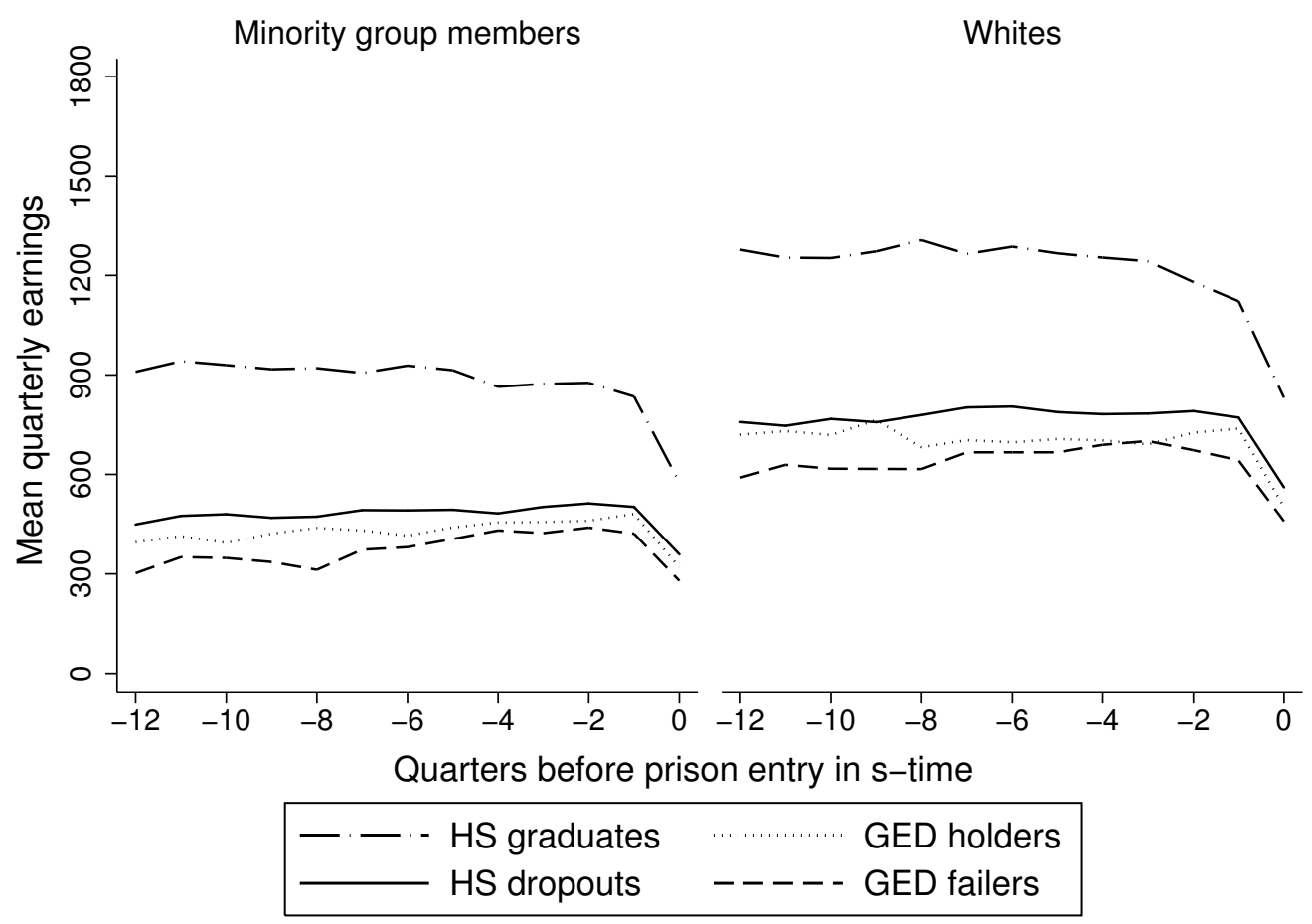

